\title{
Sığır Sayısı, Süt Üretimi ve Süt Fiyatı Arasındaki Uzun Dönem İlişkisinin Belirlenmesi: 1980-2013 Dönemi-Türkiye Örneği
}

\author{
Şenol ÇELIK* \\ Bingöl Üniversitesi, Ziraat Fakültesi, Zootekni Bölümü, Bingöl, TÜRKIYYE
}

Geliş Tarihi/Received: 04.09.2014

Kabul Tarihi/Accepted: 11.09 .2014

*Sorumlu Yazar/Correspondence: senolcelik@bingol.edu.tr

Özet: Bu çalışmada Türkiye'de sığır sayısı, sığır sütü üretimi ve sığır sütü fiyatı arasındaki ilişki, 1980-2013 dönemi temel alınarak araştırılmıştır. Sığır sayısı, sığır süt üretimi ve sığır süt fiyatı ile ilgili uzun dönem ilişkisi ele alınmıştır. Seriler arasındaki uzun dönem ilișkisi Johansen'in eş bütünleșme (koentegrasyon) yöntemi kullanılarak yapılmıștır. Eş bütünleşme için ön koşul olan serilerin durağanlığı araştırılmış ve bunların birinci mertebeden durağan olduğu görülmüştür. Eş bütünleşme analizine göre, seriler uzun dönemde birlikte hareket etmektedir, yani eş bütünleşiktir. Yapıllan analiz sonucunda sığır sütü fiyatı ve sığır sayısı arasında pozitif iliş̧kinin olduğu görülmüştür. Ancak sığır sütü fiyatı ve sığır süt miktarı arasında negatif bir ilişkinin olduğu gözlemlenmektedir.

Anahtar Kelimeler: Birim kök, eş bütünleşme, sığır sayısı, süt üretimi ve fiyatı

\section{The Determination of the Long Term Relationship Among Number of Cattle, Milk Production and Milk Price: Periods of 1980 to 2013- The Turkish Case}

\begin{abstract}
In this study, the relationships among number of cattle, cattle milk production and cattle milk price are analyzed by taking into consideration in the period between 1980-2013 in Turkey. The long-term relationships among number of cattle, cattle milk production, and cattle milk price are examined by the Johansen's cointegration method. As a precondition of the cointegration method, the stationarity of series is investigated and it is found that each of the series is the first order integrated. According to the cointegration analysis, the series move together in the long term, that is, they are cointegrated. As a result, the long-term relation between the cattle milk price and number of cattle is found to be pozitive. However, a negative relationship has been found between cattle milk price and production.
\end{abstract}

Keywords: Unit root, cointegration, number of cattle, milk production and piece

\section{Giriş}

Dünya toplam süt üretim miktarının \% 83'ünü inek sütü oluşturmaktadır. Üretim artış1, 2011 yılında bir önceki yıla göre \% 2.7 oranında gerçekleşirken, 2012 yılında toplam üretim bir önceki yıla göre $\% \quad 2.1$ artış göstermiştir. Uluslararası Karşılaştırmalı Çiftlik Veri Ağı (International Farm Comparison Network, IFCN) verilerine göre ise, 2012 y1lı toplam inek ve manda sütü üretimi bir önceki yıla göre \% 2.6 artarak toplamda 739 milyon ton olarak hesaplanmıştır (Anonymous, 2014a). Türkiye'de ise toplam süt üretim miktarının \% 91'ini inek sütü oluşturmaktadır (Anonim, 2014).

Dünyada ve Türkiye'de nüfusun artışı ile birlikte süte olan talep ve süt tüketimi de artmaktadır. Dünya nüfusunun 7.1 milyar olarak tahmin edildiği 2012 yılında, kişi başına ortalama süt tüketimi $109.1 \mathrm{~kg}$ süt eşdeğeridir. Bu rakam aynı zamanda global tüketimde son yedi yılda $\% 8$ 
(7.6 kg) artış olduğunu göstermektedir (Anonymous, 2014b).

IFCN tarafindan yapılan araştırmalara göre, 1981-2012 yılları arasında dünyada çiğ süt fiyatları $8 \$ 100 \mathrm{~kg}^{-1}$ ila $44.5 \$ 100 \mathrm{~kg}^{-1}$ arasında değişiklik göstermiştir. Çiğ süt fiyatları tarihte en yüksek seviyesine, bir önceki yıla göre \% 100 artışın gerçekleştiği 2007 yılında ulaşırken, 2009 yılında keskin bir düşüşle $26.2 \$ 100 \mathrm{~kg}^{-1}$ ' a gerilemiştir. Çiğ süt fiyatları 2010 yılındaki \% 32.5 artışla 38.8 $\$ 100 \mathrm{~kg}^{-1}$, a, 2011 yilinda ise $44.5 \$ 100 \mathrm{~kg}^{-1}$ 'a çıkmıştır. 2012 yılında ise bir önceki yıla göre \% 17 oranında bir düşüş ile ortalamada 37 \$ $100 \mathrm{~kg}^{-1}$ a gerilemiştir. 2013 y1lının ilk altı aylık dönemi için ise dünya ortalama çiğ süt fiyatı 49 \$ $100 \mathrm{~kg}^{-1}$ olarak hesaplanmıştır (Anonymous, 2014a). Türkiye'de ise ortalama süt fiyatı yaklaşık $45 \$ 100 \mathrm{~kg}^{-1}$ olarak hesaplanmıştır (Anonim, 2014).

Süt sığırcılı̆̆ı amacı kâr olan ekonomik bir faaliyet olup, milyonlarca üretici tarafindan yapılmaktadır. Aşırı rekabetin yaşandığı bu sektörde bilinçsizce ve tesadüflere bağlı olarak kâr etmek mümkün değildir. Gelişmiş ülkelerin aşırı sübvansiyonlarla desteklendiği hayvan ve hayvansal ürünler ticareti nedeniyle, son yillarda ülkemizde yaşanan olumsuzluklar meydanda olup, adeta var olma savaşı verilmektedir. 21. yüzyıl modern süt sığırcılığında yeterli bilgiye sahip yetiştirici, yüksek vasıflı damızlık materyal, yeterli ve kaliteli yem, uygun hayvan barınakları, koruyucu hekimlik ve etkin tedavi, örgütlenme, pazarlama ve kayıt sistemleri temel unsurlar olarak görülmektedir (Açıkgöz, 2010).

Sığır sütü Türkiye'de ekonomik kazanç (4.986.060.000 \$) olarak en çok değer gören ve üretim miktarı (15.977.837 ton) açısından da buğdaydan sonra ikinci sirada bulunan bir besindir (Anonymous, 2014c). Bu bilgiler sütün Türkiye için son derece önemli bir besin olduğunu göstermektedir.

Yapılan literatür taramasına göre, eş bütünleşme yöntemi ile başta ekonomi olmak üzere birçok alanda çok sayıda araştırma yapılmasına rağmen hayvancılık alanında yapılıış herhangi bir çalışmaya rastlanmamıştır. $\mathrm{Bu}$ çalışmanın amacı Johensen eş bütünleşme yöntemi kullanılarak, Türkiye'de sığır sayısı, sığır süt üretimi ve sığır sütü fiyatı arasındaki uzun dönemli ilişkilerinin araştırılmasıdır.

\section{Materyal ve Yöntem}

$\mathrm{Bu}$ araştırmada, sığır sayısı, sığır sütü üretim miktarı ve sığır sütü taban fiyatlarına ait veriler, Türkiye İstatistik Kurumu (TÜİK) ve Birleşmiş
Milletler Gıda ve Tarım Örgütü (Food and Agriculture Organization of the United Nations, FAO) sayfalarındaki kayıtlardan sağlanmıştır. Bu değişkenlere ait veriler 1980-2013 dönemi için y1llı zaman serileri seklinde oluşturularak istatistiksel analize hazır hale getirilmiştir.

Çalışmada, sığır sayısı, sığır sütü üretimi ve sığır sütü fiyatı arasındaki ilişkiyi analiz etmek için eş bütünleşme yöntemi uygulanmıştır. Bu yöntemin uygulanabilmesi için değişkenlere ait serilerin ortalama ve varyanslarının zaman içerisinde sistematik değişim göstermemesi yani serilerin durağan olması gerekir (Kenar, 2000). Durağan olmayan serilerin durağan hale dönüştürülmesi için serilerin birinci fark1 alınmakta ve nedensellik ilişkisi farkı alınan seri ile incelenmektedir (Engle ve Granger, 1987). Serilerin durağanlığını belirlemek için kullanılan en yaygın yöntem, Genişletilmiş Dickey Fuller Birim Kök Testi (Augmented Dickey-Fuller, ADF)'dir (Erdal ve ark., 2006). Serilerin durağanlık testi için ADF testinde sabit terimsiz, sabitli ve trendli (eğilimli) bir süreç izlenir. Buna göre seri eğilimli bir süreçte durağan hale gelmişse, diğer süreçler izlenmeksizin bu değer esas alınır. Seri durağan hale gelmemişse, sabit terimli, bunda da durağanlık sağlanamamışsa, sabit terimsiz sınama yapılır ve bu süreç sonucunda seriyi durağan hale getiren değer baz alınır (Enders, 1995). Dickey ve Fuller (1979, 1981) geliştirdikleri yöntemle bir serinin durağanlığını ve birim kökün varlığını test etmişlerdir. Yapılan testin, AR(1) şeklindeki birinci dereceden otoregresif bir sürece dayandığı söylenebilir (Asteriou ve Hall, 2007). Dickey ve Fuller'a göre; hata teriminin ortalamasının sıfır, normal dağılıma ve sabit bir varyansa sahip ve hata teriminin akgürültülü (white noise) olduğu kabul edilmektedir. Hata teriminin akgürültülü olmadığ durumlar için Dickey-Fuller, birim kökün varlığını test etmede kullanılan sürece, otokorelasyonu ortadan kaldırabilmek için bağımlı değişkene ait gecikme değerlerini dâhil ederek ADF testini önermişlerdir. Bu test aşağıdaki gibi üç farklı eşitlikle yazılabilir (Asteriou ve Hall, 2007).

$$
\begin{aligned}
& \Delta X_{t}=\gamma X_{t-1}+\sum_{i=1}^{k} \beta_{i} \Delta X_{t-i}+e_{t} \\
& \Delta X_{t}=\alpha_{0}+\gamma X_{t-1}+\sum_{i=1}^{k} \beta_{i} \Delta X_{t-i}+e_{t} \\
& \Delta X_{t}=\alpha_{0}+\alpha_{1} t+\gamma X_{t-1}+\sum_{i=1}^{k} \beta_{i} \Delta X_{t-i}+e_{t}
\end{aligned}
$$

ADF testi, yukarıdaki denklemde $\gamma$ katsayısının istatistiksel olarak sıfira eșit olup olmadığını test eder. ADF testi ile elde edilen 
sonuçlar, \% 1, \% 5 ve \% 10 anlamlılık düzeyinde MacKinnon (MacKinnon, 1996) kritik değerleri ile karşılaştırılabilir. Denklemde $\Delta X_{t}$ durağan olup olmadığı analiz edilen zaman serisinin birinci farkını, $\mathrm{t}$ genel eğilim değişkenini ve $X_{t-1}$ ise gecikmeli fark terimlerini göstermektedir.

Durağan olmayan değișkenlerle test edilen bir model genelde sahte regresyon olmaktadir. Modeldeki değişkenler durağan değilse değişkenlerin doğrusal bileşimleri durağan olabilmekte sahte regresyon durumu önlenebilmektedir (Çakmak ve ark., 2002). Durağan olmayan zaman serilerinin durağan hale gelmesi için serilerin çeşitli düzeylerden I(1), I(2) olarak farkları alınmaktadır. Fark alma işılemi serinin hem geçmiş dönemlerde uğradığı şokların etkisini ortadan kaldırmaktadır hem de bu şokların dışında olabilecek, uzun dönemli ilişkilerin de ortadan kalkmasına yol açmaktadır. Bu nedenle, durağanlaştırılmış seriler ile yapılan regresyon modellerinde uzun ilişkisi zayıflamaktadır. Eş bütünleşme yaklaşımı, zaman serilerinin durağan olmaması halinde, fark işlemi ile durağanlaştırılan serinin değişkenleri etkileyen dişsal şoklara rağmen, değişkenler arasında uzun dönemli bir denge ilişkisinin olabileceğini ifade etmektedir (Dikmen, 2009). Aynı düzeyde durağan değişkenlerin eş bütünleşik olup olmadıklarını belirlemek için eş bütünleşme testi yapılır (Kadılar, 2000). Değişkenler arasındaki eş bütünleşme ilişkisinin belirlenmesinde Johansen ve Juselius (1990) testleri kullanılmaktadır. Bu çalışmada da, Johansen ve Juselius eş bütünleşme ilişsisi analizi kullanılmıştır.

Serilerin farklarının alınması, değişkenlerin geçmiş dönemlerde maruz kaldığı şokların etkisini yok etmekle birlikte değişkenler arasındaki uzun dönemli ilişkilerin de ortadan kalkmasına neden olmaktadır. Dolayısıyla, değişkenler arasında uzun dönemli bir ilişkinin varlığı eş bütünleşme analizi ile belirlenebilir (Tar1, 2005). Genel olarak, Y ve X serileri $\mathrm{I}(\mathrm{d})$ ise ve $\mathrm{d}$ aynı değerse iki seri eş bütünleşiktir ve aralarındaki regresyon da güvenilir sonuçlar verecektir (Gujarati, 2006). Johansen eş bütünleşme testi, aşağıdaki regresyon modeli dikkate alınarak yapılmaktadır (Turner, 2009):

$$
\Delta X_{t}=\alpha\left(\beta^{\prime} X_{t-1}-\beta_{0}-\beta_{1 t}\right)-\gamma_{0}-\gamma_{1 t}+\sum_{j=1}^{k} \Gamma_{j} \Delta X_{t-j}+\varepsilon_{j}
$$

Burada; $X_{t}$, t döneminde gözlenen değişkenlerin px1 vektörü; $\alpha$, pxr katsayılar matrisi; $\beta, \mathrm{r}$ eş bütünleşik vektörlerini tanımlayan pxr katsayılar matrisi; $\beta_{0}$, eş bütünleşik vektörler için kesikli rx1 vektörü; $\beta_{1}$, eş bütünleşik vektörlerde lineer deterministik eğilimlerine olanak sağlayan rx1 katsayılar vektörü; $\gamma_{0}$, denklemdeki px1 kesikli vektörü; $\gamma_{1}$, px1 lineer eğilim katsayılar vektörü ve
$\Gamma_{j}, \mathrm{j}=1 \ldots$ k'ya kadar olan ve gecikme uzunluğu olan pxp matrislerini ifade etmektedir.

Farklı eş bütünleşik vektörlerin sayısı П matrisinin karakteristik (öz değerler) köklerinin yeterliliğinin sınanması ile elde edilebilir. Matrisin rankı sıfırdan farklı öz değerlerin sayısına eșittir. Eşanlı denklemler için Maksimum Olabilirlik (Maximum Likelihood Estimator) yöntemi kullanılarak $\lambda$ öz değerleri;

$$
\left|\lambda \mathrm{S}_{11}-\mathrm{S}_{10} \mathrm{~S}_{00}^{-1} \mathrm{~S}_{01}\right|=0
$$

şeklinde çözülerek $\Pi$ matrisinin $n$ öz değerleri $r$ en büyük öz değerler $1>\lambda_{1}>\lambda_{2}>\ldots \ldots . \lambda_{\mathrm{r}}>\ldots . \lambda_{\mathrm{n}}>0$ şeklinde stralanabilir (Hendry, 1995; Johansen, 1995). $X_{t}$ deki değişkenler eş bütünleşik olmamışlarsa $\Pi$ matrisinin rankı sıfira eşit olacak ve bütün öz değerler sıfır olacaktır. $\operatorname{Ln}(1)$ değeri sıfır olduğundan, $\ln \left(1-\lambda_{\mathrm{i}}\right)$ değeri doğrudan sıfira eşit olacaktır. Eğer matrisin rank1 bir ve $0<\lambda 1<1$ arasında değişiyor ise, $\ln \left(1-\lambda_{1}\right)$ nin değeri negatif olurken diğer bütün öz değerler sıfır olacaktır. Öz değerlerin sayısını test etmede Eşitlik 6'da kullanılan denklemlerde $\lambda_{\mathrm{i}}$ tahmin edilen öz değerleri göstermektedir. $\mathrm{T}$ ise gözlem sayısıdır, r'nın değeri bilindiğinde test bu iki denklemin alacağı değerler arasında yapılır (Enders, 1995).

$$
\begin{aligned}
& \lambda_{\text {trace }}(r)=-T \sum_{i=r+1}^{n} \ln \left(1-\hat{\lambda}_{i}\right) \\
& \lambda_{\max }(r, r+1)=-T \ln \left(1-\hat{\lambda}_{r+1}\right)
\end{aligned}
$$

\section{Bulgular ve Tartışma}

Çalışmada, önce serilerin durağanlık özellikleri incelenmiştir. Granger ve Newbold (1974)'un belirttiği gibi durağan olmayan seriler kullanılarak yapılan tahminde sahte regresyon sorunu ortaya çıkmaktadır. Bu durumda, serilerin durağanlığının incelenmesinde birim kök testleri geliștirilmiştir. $\mathrm{Bu}$ testlerin bir bölümü serilerdeki yapısal kırılmayı dikkate almadan diğer bir bölümü serideki yapısal kırılmayı dikkate alarak, serinin durağan olup olmadığını incelemektedir. Perron (1989), yapısal kırılma halinde, bu kırılmayı dikkate almayan birim kök testlerinin sapmalı sonuçlar vereceğini belirtmektedir. Çalışmada belirlenen dönem aralığı içerisinde incelenen serilerin durağanlık durumlarının araştırılmasında, yapısal kırılma görülmemiştir.

Şekil 1, Şekil 2 ve Şekil 3'te sırasıyla 19802013 dönemine ait sığır sayısı, sığır sütü üretimi ve sığır sütü taban fiyatı grafikleri verilmiştir. Ayrıca, 
serilerin birinci farklarına ait grafikler Şekil 4-6'da verilmiştir. Şekil 4'te sı̆ğr sayısı, Şekil 5'te süt üretimi ve Şekil 6'da süt fiyatı için birinci fark1 alınmış serilerin grafikleri incelendiğinde, trende (eğilime) sahip olmadıkları görülmektedir.

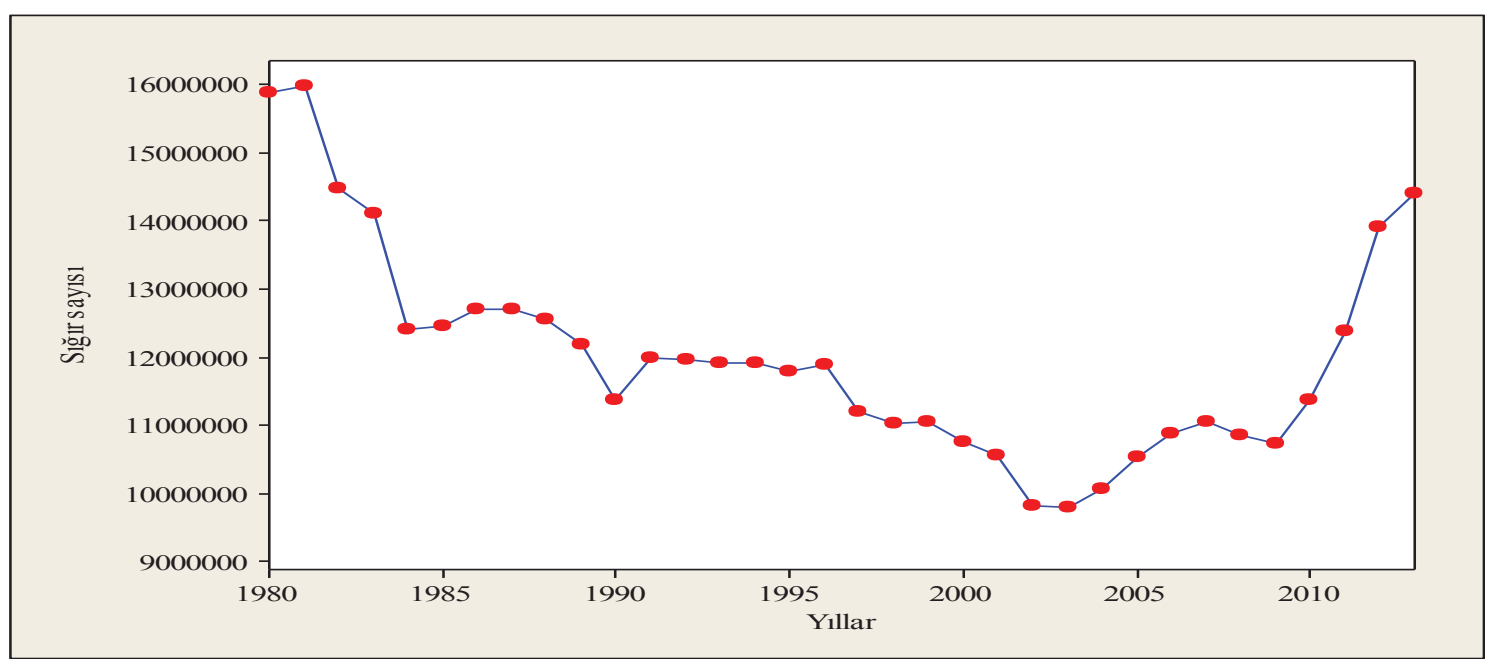

Şekil 1. 1980-2013 dönemi sığır sayısı

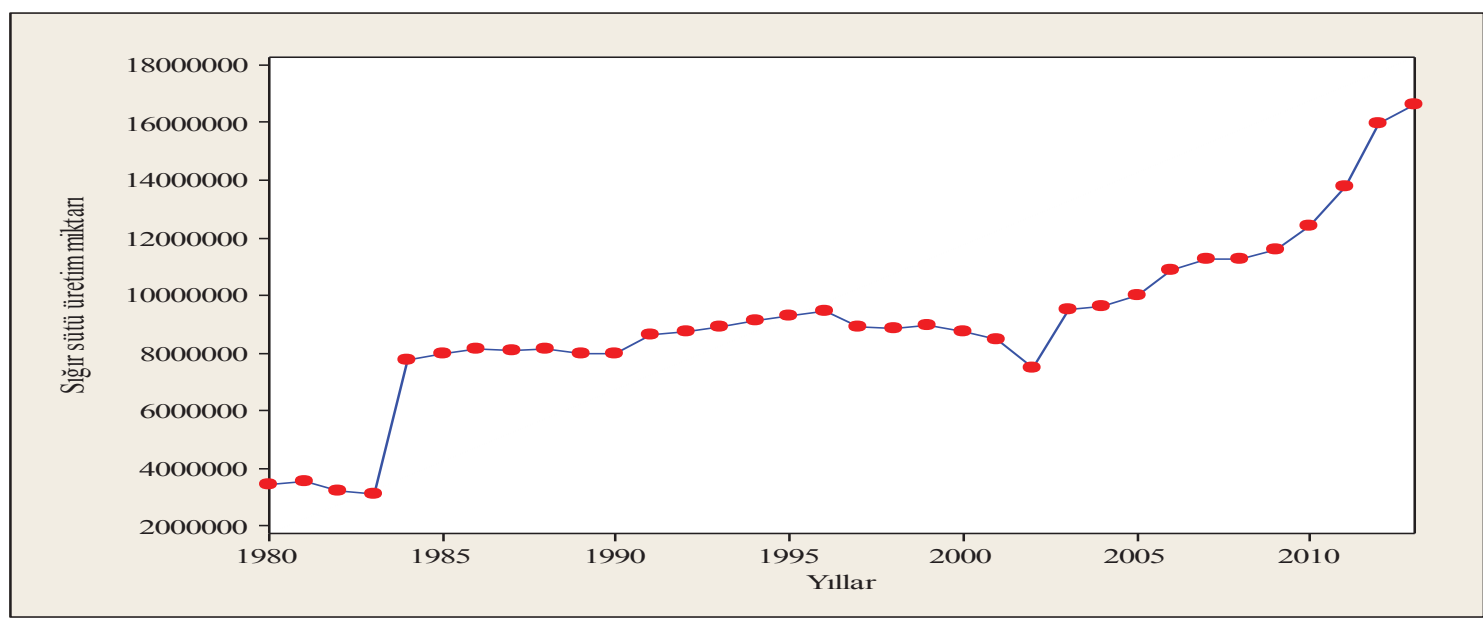

Şekil 2. 1980-2013 dönemi sığır sütü üretimi (ton)

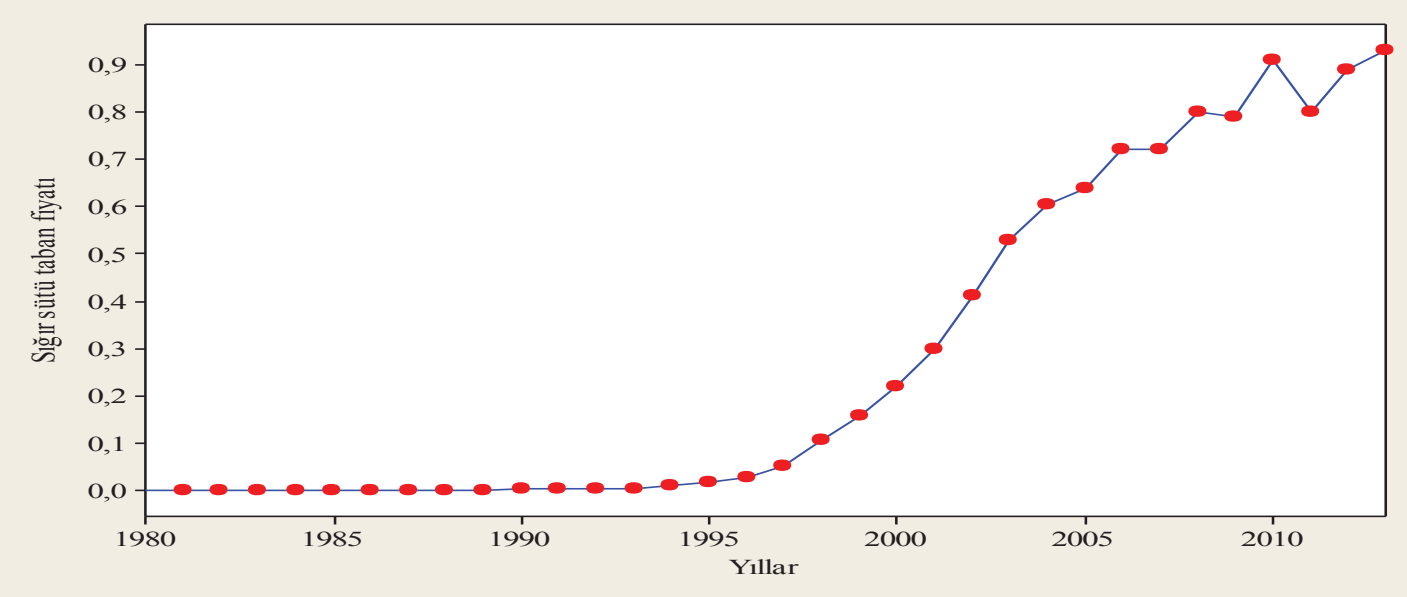

Şekil 3. 1980-2013 dönemi sığır sütü taban fiyatı (TL kg-1) 


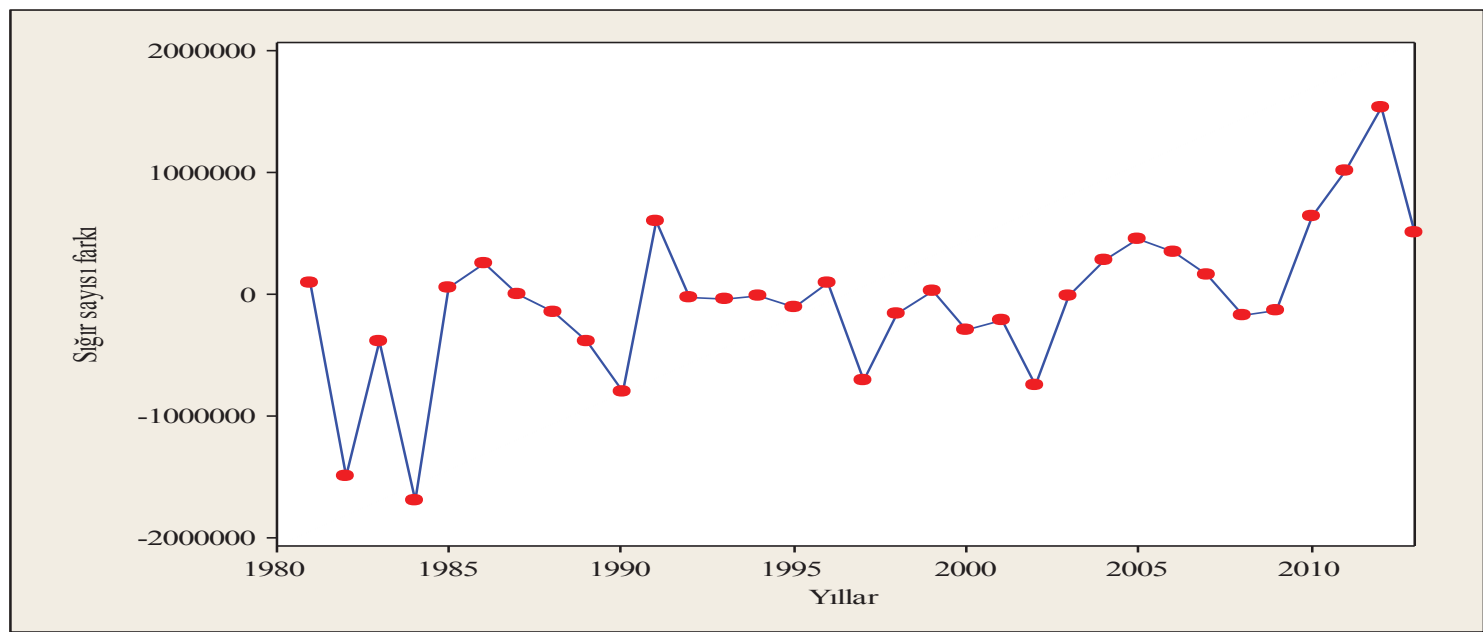

Şekil 4. Birinci dereceden farkı alınmış sığır sayısı serisi

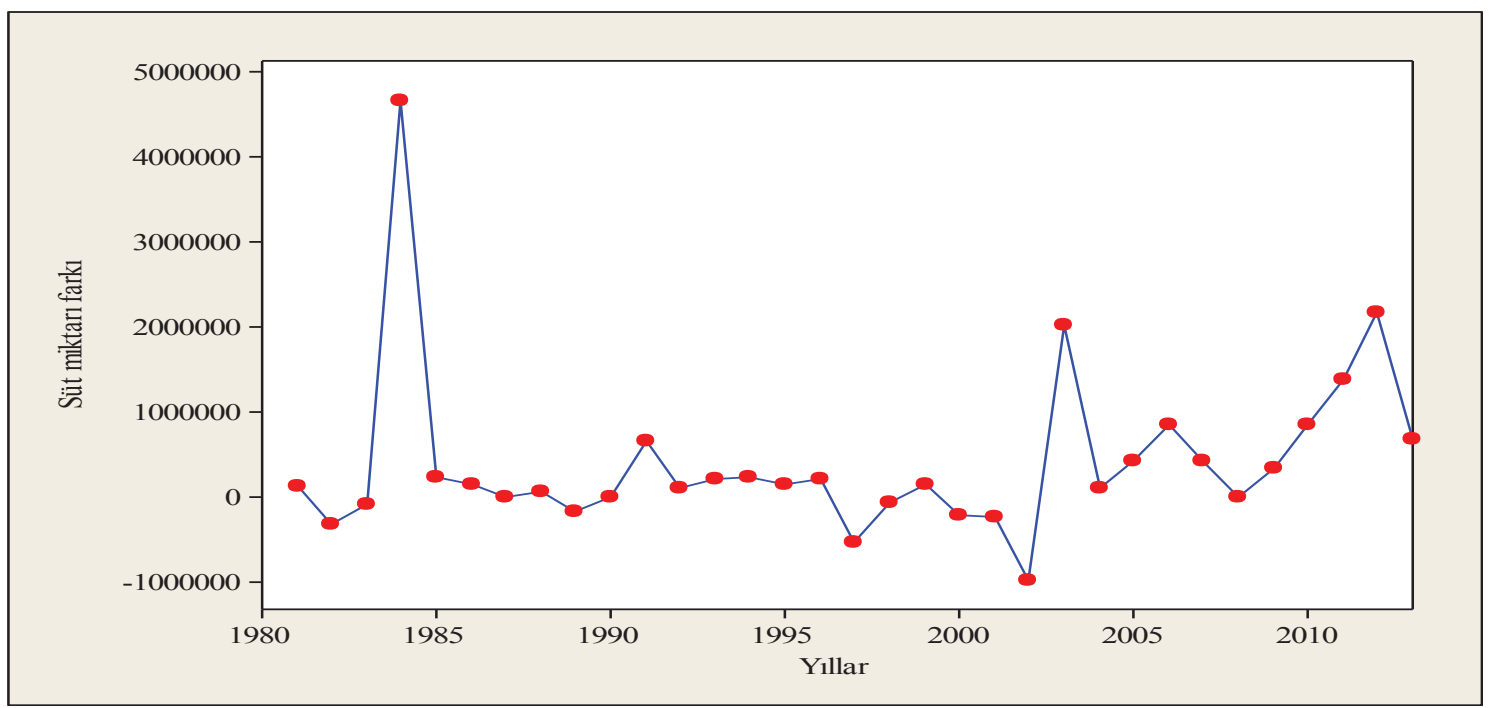

Şekil 5. Birinci dereceden farkı alınmış süt üretimi serisi

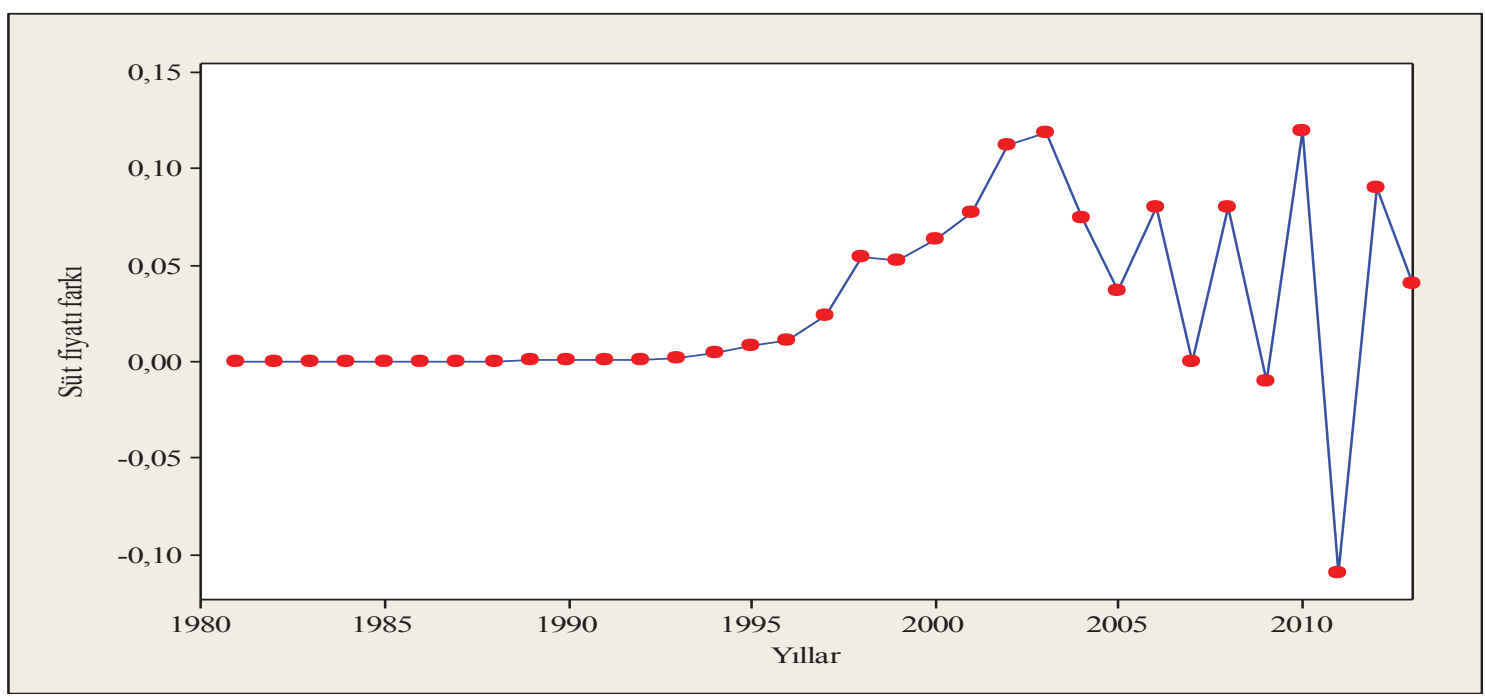

Şekil 6. Birinci dereceden farkı alınmış süt fiyatı serisi 
Tablo 1'de görüldüğü gibi, sığır sayısı, süt miktarı ve süt fiyatı değişkenlerine ait serilerin durağanlık durumları Augmented Dickey-Fuller birim kök testi ile incelendiğinde düzey değerlerinde durağan olmadıkları görülmüştür. Serilerin birinci farklarında durağan oldukları görülmüştür. Modeldeki gecikme sayısı Akaike bilgi kriterine göre 8 olarak belirlenmiştir. Akaike kriteri en küçük olan model en küçük olan gecikme sayısına sahip model en uygun model olarak kabul edilir. Modelin hata terimleri akgürültülüdür (White noise) (Kadilar, 2000).

Tablo 1. ADF Birim kök testi sonuçları

\begin{tabular}{llcl}
\hline Değişken & Derece & $\begin{array}{c}\text { ADF } \\
\text { t istatistiği }\end{array}$ & \\
\hline SS & Düzey & 0.038 & 0.995 \\
& Birinci fark & -5.326 & $0.001^{*}$ \\
\hline SU & Düzey & -1.351 & 0.857 \\
& Birinci fark & -5.330 & $0.001^{*}$ \\
\hline SF & Düzey & -1.880 & 0.640 \\
& Birinci fark & -4.056 & $0.020^{*}$ \\
\hline
\end{tabular}

*:MacKinnon kritik değerleri \% 1, \% 5 ve \% 10 anlamlılık düzeyleri için sırası ile $-4.273,-3.553$ ve -3.212 seklindedir. Gecikme sayısı 8'dir, SS: Sığır sayısı, SU: Sığır sütü üretim miktarı (ton), SF: Sığır sütü taban fiyatı $\left(\mathrm{TL} \mathrm{kg}^{-1}\right)$
Eş bütünleşme analizi sonuçlarına göre sığır sayısı, sığır sütü üretim miktarı ve sığır sütü taban fiyatı serileri arasında uzun dönemli bir ilişki vardır. $\mathrm{Bu}$ sonuca $\lambda_{\max }$ ve $\lambda_{\text {trace }}$ istatistiğ değerleriyle $\% \quad 5$ anlam düzeyindeki tablo değerlerinin karşılaştırılması ve $p<0.05$ değeri ile ulaşılabilmektedir. Tablo 2'de görüldüğü gibi “eş bütünleşme denklemi oluşturulamaz" şeklindeki yokluk hipotezi $\lambda_{\max }=21.805$ ve $\lambda_{\text {trace }}=31.758$ değerlerinin tablo değerlerinden büyük bir değer olması nedeniyle reddedilebilmektedir.

Eş bütünleşik vektör sayısını bulmak için yapılan eş bütünleşme testinde en az bir eş bütünleşik vektörün olduğu Tablo 2'de görülmektedir. Tablo 2'de $\lambda_{\mathrm{i}}$ öz değerlerini gösterirken eş bütünleşik vektör bulunmadığını ifade eden $\mathrm{H}_{0}$ hipotezi $\left(\mathrm{H}_{0}: \mathrm{r}=0\right)$, en az bir eş bütünleşik vektör bulunduğunu ifade eden $\mathrm{H}_{1}$ hipotezine $\left(\mathrm{H}_{1}: r \neq 0\right)$ karş1 test edilmekte ve sonuçta bir eş bütünleşik vektörün olduğu görülmektedir. Yani bir tane eş bütünleşme denklemi yazılabilir. Dolayısıyla seriler arasında uzun dönemli bir adet denklem yazılabilmekte, yani seriler arasında uzun dönemli bir ilişki olmaktadır.

Tablo 2. Eş bütünleşme testi

\begin{tabular}{lcrrrrrr}
\hline $\begin{array}{l}\text { Öz değer } \\
(\lambda)\end{array}$ & $\mathrm{H}_{0}$ : rank=p & $\lambda_{\max }$ & $\% 95$ & $\mathrm{p}$ & $\lambda_{\text {trace }}$ & $\% 95$ & $\mathrm{p}$ \\
\hline 0.505071 & $r=0$ & 21.805 & 21.132 & 0.040 & 31.758 & 29.797 & 0.029 \\
0.232470 & $r \leq 1$ & 8.202 & 14.265 & 0.359 & 9.955 & 15.495 & 0.284 \\
0.054967 & $r \leq 2$ & 1.753 & 3.841 & 0.186 & 1.753 & 3.841 & 0.186 \\
\hline
\end{tabular}

Tablo 3'te bir eş bütünleşik vektörünün olduğu durum görülmektedir.

Eş bütünleşme denklemi,

$$
\begin{aligned}
& \mathrm{SF}=0.0000000685 \mathrm{SS}-0.000000183 \mathrm{SU} \\
& (0.00000005)
\end{aligned}
$$

şeklindedir. $\mathrm{Bu}$ denkleme göre süt üretim miktarında bir birimlik değişme süt fiyatında 0.000000183 birimlik bir azalışa, sığır sayısındaki bir birimlik artış süt fiyatında 0.0000000685 birimlik bir artışa neden olacaktır. Kısaca eş bütünleșik vektöre bakıldığında süt fiyatı, süt üretimi ile negatif yönlü sığır sayısı ile pozitif yönlü ilişkilidir. Ayrıca katsayıların testi yapıldığında SS (sığır sayısı) katsayısı istatistiki olarak önemsiz, yani sığır sayısının süt fiyatı üzerinde uzun dönemli etkisi olmamıştır. Ancak SU (süt üretimi) katsayısı istatistiki olarak önemli olduğundan, süt üretiminin süt fiyatı üzerinde uzun dönemli etkisi olmuştur.
Tablo 3. Bir eş bütünleşik vektörünün olduğu durum ve ayarlama katsayıları

\begin{tabular}{lll}
\hline SF & SU & SS \\
\hline 1.000 & 0.000000183 & -0.0000000685 \\
\hline \multicolumn{3}{c}{ Ayarlama katsayilar1 ve standart hatalar1 } \\
\hline $\mathrm{D}(\mathrm{SF})$ & -0.046623 \\
& $(0.06233)$ \\
\hline $\mathrm{D}(\mathrm{SU})$ & -5939248 \\
& $(1603414)$ & \\
\hline $\mathrm{D}(\mathrm{SS})$ & 2104551 & \\
& $(741696)$ & \\
\hline
\end{tabular}

değerler ayarlama katsayılarının standart hatalarıdır

\section{Sonuçlar}

Türkiye'nin 1980-2013 dönemi sığır sayısı, sı̆̆ır sütü üretimi ve sığır sütü fiyatını içeren bu çalışmada serilerin durağan olmadıkları ancak birinci farkı alındıktan sonra yapılan genişletilmiş Dickey-Fuller birim kök testleriyle durağan hale geldiği görülmüștür. Serilerin birinci farkının grafiklerinden de görüldüğü gibi trendden (eğilimden) arındırılarak durağan hale geldiği 
görülmüştür. $\mathrm{Bu}$ nedenle incelenen değişkenler arasındaki uzun dönem ilişkisini araştırmak amacıyla eş bütünleme analizini gerçekleştirmek mümkün olmuştur. Yapılan analizle değişkenler arasında uzun dönem ilişkisinin olduğu saptanmıştır. Değişkenler arasında bir eș bütünleşik vektörünün olduğu belirlenmiştir. Yapılan uzun dönem tahmini ile sığır sayısında meydana gelecek artış süt fíyatlarında artışa neden olacak yani sığır sayısı ile süt fiyatı arasında pozitif yönlü bir ilişki mevcuttur. Süt üretimindeki artış süt fiyatları da düşürecektir. Burada süt üretimi ile süt fiyatı arasında negatif yönlü bir ilişki vardır. Bunun sonucunda süt üretiminin artması fiyatı düşürdügünden tüketicilerin alım gücünün artması açısından olumlu bir gelişme olabilir. Sığır sayısının artmasına karşın süt fiyatlarında düşüş olmamıştır.

\section{Kaynaklar}

Açıkgöz, M., 2010. Kârlı bir süt sığırcılığı nasıl yapılır? (Kârlılıkta 40 önemli nokta). Süt Hayvancılığ 1 Eğitim Merkezi Yayınları, Hayvancılık Serisi: 5, Yetiştirici El Kitabı, Bursa.

Anonim, 2014. Hayvancılık İstatistikleri, TÜİK. http://tuikapp.tuik.gov.tr/hayvancilikapp/hayvancilik .zul (Erişim tarihi: 27.08.2014).

Anonymous, 2014a. International Farm Comparison Network, IFCN. http://www.ifcndairy.org/en/start/ index.php (Erişim tarihi: 18.08.2014).

Anonymous, 2014b. International Dairy Federation, IDF. http://www.fil-idf.org/Public/ColumnsPage.php ?ID=23077 (Erişim tarihi: 12.07.2014).

Anonymous, 2014c. FAO, Food and Agriculture Organization of the United States. http://faostat.fao.org/site/339/default.aspx (Erişim tarihi: 17.08.2014)

Asteriou, D., Hall, S., 2007. Applied Econometrics. A Modern Approach Using Eviews and Microfit, New York.

Çakmak, E., Aksu, H., Opuş, S., 2002. Türkiye'de ithalat talebi ve esnekliklerinin ekonometrik analizi: 1987-2000. Atatürk Üniversitesi Íktisadi ve İdari Bilimler Dergisi, 16(5-6): 16-31.

Dickey, D.A., Fuller, W.A., 1979. Distribution of the estimators for autoregressive time series with a unit root. Journal of the American Statistical Association, 74(366): 427-431.
Dickey, D.A., Fuller, W.A., 1981. Likilihood ratio statistics for autoregressive time series with a unit root. Econometrica, 49(4): 1057-1072.

Dikmen, N., 2009. Ekonometri Temel Kavramlar ve Uygulamalar. Nobel Yayınevi, Ankara.

Enders, W., 1995. Applied Econometris Time Series. John Wiley and Sons, New York, 256.

Engle, R.F., Granger, C.W.J., 1987. Co-Integration and error correction: Representation, estimation, and testing. Econometrica, 55(2): 251-276.

Erdal, G., Erdal, H., Esengün, K., 2006. Türkiye' de eğitim ve ekonomik büyüme arasındaki nedensellik ilişkisi. Türkiye VII. Tarım Ekonomisi Kongresi, 1315 Eylül, Antalya, (1): 264-275.

Granger, C.W.J., Newbold, P., 1974. Spurious regressions in econometrics. Journal of Econometrics, 2: 111-120.

Gujarat1, D.N., 2006. Temel Ekonometri (Çev: Ü. Şenesen ve G.G. Şenesen), 4. Bask1, Literatür Yayıncılık, İstanbul.

Hendry, D.F., 1995. Dynamic Econometrics. Oxford University Pres., New York, p. 415-416.

Johansen, S., 1995. Likelihood Based Inference in Cointegrated Vector Autoregressive Models. Oxford University Pres., New York.

Johansen, S., Juselius, K., 1990. Maximum likelihood estimation and inference on cointegration with applications to the demand for money. Oxford Bulletin of Economics and Statistics, 52(2): 169209.

Kadılar, C., 2000. Uygulamalı Çok Değișkenli Zaman Serileri Analizi. Bizim Büro Basımevi, Ankara.

Kenar, N., 2000. Kamu harcamalarının ekonomiye etkileri: Türkiye üzerine uygulamalı bir çalışma. Doktora tezi (Yayınlanmamış), Gazi Üniversitesi, Ankara.

MacKinnon, J.G., 1996. Numerical distribution functions for unit root and cointegration tests. $J$. Applied Econm., 11: 601-618.

Perron, P., 1989. The great crash, the oil price shocks, and the unit root hypothesis. Econometrica, 57(6): 1361-1401.

Tar1, R., 2005. Ekonometri. 3. Bask1, No: 172, Kocaeli Üniversitesi Yayınları, İstanbul.

Turner, P., 2009. Testing for cointegration using the johansen approach: Are we using the correct critical values. Journal of Applied Econometrics, 24: 825831. 